\title{
The Tiananmen Incident and the Pro-Democracy Movement in Hong Kong
}

Joseph Cheng

\section{(2) OpenEdition \\ Journals}

Electronic version

URL: http://journals.openedition.org/chinaperspectives/4811

DOI: 10.4000/chinaperspectives.4811

ISSN: 1996-4617

\section{Publisher}

Centre d'étude français sur la Chine contemporaine

\section{Printed version}

Date of publication: 1 June 2009

Number of pages: $91-100$

ISSN: 2070-3449

\section{Electronic reference}

Joseph Cheng, «The Tiananmen Incident and the Pro-Democracy Movement in Hong Kong », China Perspectives [Online], 2009/2 | 2009, Online since 01 June 2011, connection on 28 October 2019. URL : http://journals.openedition.org/chinaperspectives/4811; DOI : 10.4000/chinaperspectives.4811

This text was automatically generated on 28 October 2019

(C) All rights reserved 


\section{The Tiananmen Incident and the Pro-Democracy Movement in Hong Kong}

Joseph Cheng

\section{ABSTRACTS}

While refusing to allow any erosion of the Communist Party's monopoly of political power, the Chinese leadership has proven very skilful in meeting emerging challenges in the era of economic reform and opening to the outside world since the Tiananmen Incident. Retaining its belief that economic growth remains the key to Hong Kong's social and political stability, the Chinese government preserves the united front framework in its Hong Kong policy, with no intention of introducing genuine democracy.

\section{AUTHOR}

\section{JOSEPH CHENG}

Professor of Political Science and Director of the Contemporary China Program at the City University of Hong Kong. 